ISSN 2412-608X. Масличные культуры. Вып. 1 (177), 2019

\section{Селекционны достижения}

УДК 633.853.52:631.52

DOI 10.25230/2412-608X-2019-1-177-138-142

\section{Среднеранний сорт сои Барс}

\section{С.В. Зеленцов,}

доктор сельскохозяйственных наук

Е.В. Мошненко,

кандидат биологических наук

Г.М. Саенко,

кандидат биологических наук

М.В. Трунова,

кандидат биологических наук

А.А. Ткачёва,

кандидат сельскохозяйственных наук

Е.Н. Будников,

старший научный сотрудник

Л.А. Бубнова,

младший научный сотрудник

С.А. Рамазанова,

кандидат биологических наук

ФГБНУ ФНЦ ВНИИМК

Россия, 350038, г. Краснодар, ул. им. Филатова, д. 17

Тел.: (861) 275-86-53

E-mail: soya@vniimk.ru

Для цитирования: Зеленцов С.В., Мошненко Е.В., Саенко Г.М., Трунова М.В., Ткачёва А.А., Будников Е.Н., Бубнова Л.А., Рамазанова С.А. Среднеранний сорт сои Барс // Масличные культуры. 2019. - Вып. 1 (177). - С. 138-142.

Ключевые слова: соя, устойчивость к пепельной гнили, урожайность, засухоустойчивость, молекулярный паспорт.

Среднеранний сорт сои Барс выведен из среднеспелого сорта Парма по признакам повышенной устойчивости к пепельной гнили и засухоустойчивости. Устойчивость к пепельной гнили у этого сорта определяется пониженным осмотическим давлением клеточного сока в тканях растений. По результатам сортоиспытания 2015-2017 гг. сорт Барс по урожайности превысил стандартный сорт Славия на 0,06 т/га. Высота растений на широте Краснодара $\left(45^{\circ}\right)-87-107$ см. Новый сорт сои Барс отличается высокой устойчивостью к пепельной гнили и повышенной урожайностью в засушливых условиях. Это позволяет его возделывать в основных посевах в соепроизводящих хозяйствах Северокавказского, Нижневолжского и Дальневосточного регионов Российской Федерации на географических широтах от 43 до $50^{\circ}$, а также в Республиках Казахстан, Узбекистан и Кыргызстан.

\section{UDC 633.853.52:631.52}

A middle-early maturing soybean cultivar Bars. 138
S.V. Zelentsov, doctor of agriculture

E.V. Moshnenko, $\mathrm{PhD}$ in biology

G.M. Saenko, $\mathrm{PhD}$ in biology

M.V. Trunova, $\mathrm{PhD}$ in biology

A.A. Tkachyova, $\mathrm{PhD}$ in agriculture

E.N. Budnikov, senior researcher

L.A. Bubnova, junior researcher

S.A. Ramazanova, $\mathrm{PhD}$ in biology

All-Russia Research Institute of Oil Crops by Pustovoit V.S. (VNIIMK)

17, Filatova str., Krasnodar, 350038, Russia

Tel.: (861) 275-86-53

E-mail: soya@vniimk.ru

Key words: soybean, resistance to charcoal rot, productivity, drought resistance, molecular passport.

A middle-early maturing soybean cultivar Bars is developed from the middle maturing cultivar Parma by traits of increased resistance to charcoal rot and drought resistance. Resistance to charcoal rot in this cultivar is determined by the reduced osmotic pressure of cell sap in plant tissues. Based on the results of the variety testing of 2015-2017, seed yield of the cultivar Bars exceeded the standard cultivar Slavia by $0.06 \mathrm{t}$ per ha. The plant height is $87-107 \mathrm{~cm}$ at the latitude of Krasnodar $\left(45^{\circ}\right)$. The new soybean cultivar Bars is highly resistant to charcoal rot and differ with increased yield in arid conditions. This allows it to be cultivated in the spring sowing in soybean-producing farms of the North Caucasian, Low Volga and Far East regions of the Russian Federation on geographic latitudes from 43 to $50^{\circ}$, as well as in the Republics of Kazakhstan, Uzbekistan and Kyrgyzstan.

В последние десятилетия в России и на Северном Кавказе отмечается последовательное увеличение площадей, занятых под промышленными посевами сои. При этом рост объёмов производства культуры осуществляется на фоне развивающегося потепления климата, за последние 30 лет уже вызвавшего в регионе последовательное увеличение среднегодовой температуры в регионе более чем на $1{ }^{\circ} \mathrm{C}$, а также продолжительности и интенсивности летних засух [1]. Одновременно с потеплением и аридизацией глобального и регионального климата в большинстве соепроизводящих регионов мира наблюдается увеличение распространения гриба Macrophomina phaseolina (Tassi) Goid. возбудителя пепельной гнили, также известного в США под характерным названием «dry-weather wilt»- «увядание сухой погоды». В связи с расширением площади посева сои на Северном Кавказе и возрастающей вероятностью развития $M$. 
phaseolina в промышленных посевах сои, актуальным является создание засухоустойчивых сортов сои, не поражающихся пепельной гнилью $[8 ; 9 ; 10]$.

Однако все попытки развернуть мировую селекцию сои на устойчивость к пепельной гнили не приводили к заметному успеху. Несмотря на изредка обнаруживаемые в отдельных странах формы сои с повышенной устойчивостью к этому грибу, все попытки получить с их участием стабильно устойчивое к пепельной гнили потомство оказывались безуспешными [8].

Наши предыдущие исследования показали, что устойчивость к пепельной гнили растений сои в засушливых условиях определяется пониженным осмотическим давлением клеточного сока (ОДКС) в тканях стебля [8; 9]. На основе проведённых исследований был разработан метод выделения сортообразцов сои с повышенной устойчивостью к пепельной гнили путём отбора форм с пониженным ОДКС в критические по водопотреблению фазы развития растений [3; 8].

В 2007 г. с использованием данного метода при оценке ОДКС потомств индивидуальных растений сои из среднеспелого сорта Парма была выделена сублиния Парма-Т с пониженными уровнями ОДКС в онтогенезе. Эта линия даже в острозасушливых условиях отличалась повышенной продуктивностью и высокой устойчивостью к возбудителю пепельной гнили [8].

Всестороннее изучение линии сои Парма-Т в период 2012-2015 гг. показало, что помимо устойчивости к пепельной гнили этот сортообразец в оптимальных условиях выращивания также отличался повышенным накоплением белка в семенах, причём без снижения семенной продуктивности растений. Отсутствие отрицательной корреляции между урожайностью этой линии и содержанием белка в семенах соответствует наиболее эффективной, кумулятивно-протеиновой модели сорта, характеризующейся высокой продуктивностью в сочетании с повышенным содержанием белка [2].

Оценка устойчивой к пепельной гнили линии Парма-Т под селекционным номером Л-2717/15 в питомниках предварительного и конкурсного сортоиспытания, показала, что по основным хозяйственно ценным признакам она не уступает высокоурожайному сорту-стандарту Славия. В 2017 г. под коммерческим названием Барс эта линия была передана на Государственное сортоиспытание.

Урожайность среднераннего сорта сои Барс в конкурсном сортоиспытании была близка к сорту-стандарту Славия и даже несколько превышала его (табл. 1).

Таблица 1

Характеристика среднераннего сорта Барс

ЦЭБ ВНИИМК, 2015-2017 гг.

\begin{tabular}{|c|c|c|c|c|c|}
\hline \multirow[b]{2}{*}{ Сорт } & \multirow{2}{*}{\begin{tabular}{|c} 
Вегета- \\
цион- \\
ный \\
период, \\
сут.
\end{tabular}} & \multicolumn{3}{|c|}{ Урожайность, т/га } & \multirow[b]{2}{*}{$\begin{array}{c}\text { Сред- } \\
\text { нее }\end{array}$} \\
\hline & & $\begin{array}{c}2015 \\
\Gamma .\end{array}$ & $\begin{array}{c}2016 \\
\Gamma .\end{array}$ & $\begin{array}{c}2017 \\
\Gamma .\end{array}$ & \\
\hline Барс & 111 & 1,68 & 1,74 & 2,63 & 2,02 \\
\hline Славия (стандарт) & 108 & 1,65 & 1,72 & 2,51 & 1,96 \\
\hline Отклонение от стандарта \pm & +3 & $+0,03$ & $+0,02$ & $+0,12$ & $+0,06$ \\
\hline $\mathrm{HCP}_{05}$ & - & 0,14 & 0,15 & 0,18 & - \\
\hline
\end{tabular}

Вегетационный период нового сорта на широте Краснодара $\left(45^{\circ}\right)$, в зависимости от метеоусловий года варьировал от 102 до 117 суток и в среднем за 2015-2017 гг. составил 111 суток.

Высота растений сорта Барс на широте Краснодара - от 87 до 107 см. Во влажные годы и на более высоких географических широтах (48-50 ) высота растений может увеличиться до 110-125 см. Нижние бобы при оптимальной густоте стояния растений (350-400 тыс. раст./га) располагаются на высоте 14-16 см от поверхности почвы (рис. 1).

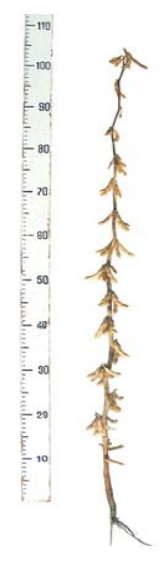

Рисунок 1 - Растение сорта Барс 
Тип развития куста по международному классификатору UPOV полудетерминантный. По классификатору типов роста сои ВНИИМК [5] сорт Барс также относится к полудетерминантному (полуограниченному) типу роста (код типа роста SD4) с удлинённым периодом цветения, завершающимся в период начала налива семян в бобах нижних узлов.

На географических широтах $45 \pm 2^{\circ}$ фенотип растений сорта Барс, по внутривидовой классификации сои ВНИИМК, соответствуют среднестебельному сортотипу - cc. medicaulis Zel. et Koch. северокавказской эколого-географической группы маньчжурского подвида сои ssp. manshurica (Enken) Zel. et Koch. На более высоких широтах $\left(48-50^{\circ}\right)$, из-за удлинённого фотопериода, фенотип сорта Барс может приобретать признаки мощного сортотипа - cc. athlanta Zel. et Koch. Ha более южных широтах $\left(38-42^{\circ}\right)$ фенотип растений сорта Барс будет приближаться к раннему сортотипу - cс. praecox (Enk.) Zel. et Koch. [4].

Окраска опушения растений серая. Окраска бобов от бежевой до светлокоричневой. Окраска венчика цветка фиолетовая. Семенная оболочка жёлтая, в оптимальных условиях созревания без пигментации (рис. 2). В острозасушливые годы и на фоне пониженных температур на оболочке семян из верхних узлов растений может формироваться коричневая пигментация. Рубчик семени светлокоричневый.

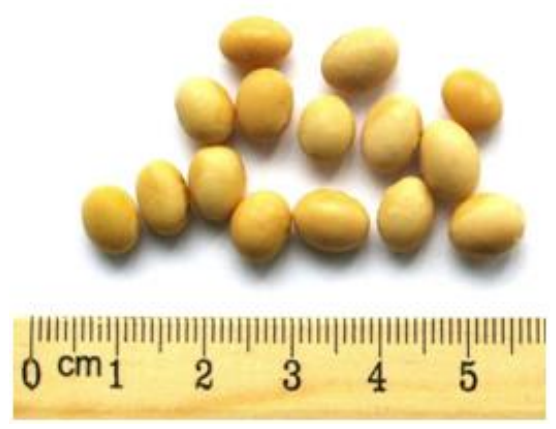

Рисунок 2 - Размеры, форма и окраска семян сорта Барс

При выращивании сорта Барс на богаpe, особенно в засушливых условиях, масса 1000 семян составляет 114-149 г. Однако в годы с достаточным количеством осадков в фазы формирования и налива семян и на орошении масса 1000 семян этого сорта может увеличиться до 160-180 г. Глубина проникновения центрального корня в почву достигает 1,92,4 м, что обеспечивает растениям сорта Барс повышенную засухоустойчивость при пересыхании верхних горизонтов почвы. Сорт высокоустойчив к пепельной гнили и фузариозу. Содержание белка в семенах сорта Барс при выращивании в условиях центральной почвенно-климатической зоны Краснодарского края и с наличием на почве специализированных азотфиксирующих бактерий составляет 40,9-45,5 \%. Содержание масла в семенах 18,5-24,7 \% (табл. 2).

Таблица 2

\section{Биохимическая характеристика семян сорта Барс}

ЦЭБ ВНИИМК, 2015-2017 гг.

\begin{tabular}{|l|c|c|c|c|c|c|c|c|}
\hline \multirow{2}{*}{ Сорт } & \multicolumn{3}{|c|}{ Содержание белка, \% } & \multicolumn{4}{c|}{ Содержание масла, \% } \\
\cline { 2 - 9 } & $\begin{array}{c}2015 \\
\text { г. }\end{array}$ & $\begin{array}{c}2016 \\
\text { г. }\end{array}$ & $\begin{array}{c}2017 \\
\text { г. }\end{array}$ & $\begin{array}{c}\text { сред- } \\
\text { неe }\end{array}$ & $\begin{array}{c}2015 \\
\text { г. }\end{array}$ & $\begin{array}{c}2016 \\
\text { г. }\end{array}$ & $\begin{array}{c}2017 \\
\text { г. }\end{array}$ & $\begin{array}{c}\text { сред- } \\
\text { неe }\end{array}$ \\
\hline Барс & 45,5 & $36,3 *$ & 41,0 & 40,9 & 18,5 & 24,7 & 22,7 & 22,0 \\
\hline $\begin{array}{l}\text { Славия } \\
\text { (стандарт) }\end{array}$ & 41,7 & $35,7 *$ & 39,5 & 39,0 & 20,1 & 24,9 & 23,3 & 22,8 \\
\hline $\begin{array}{l}\text { Отклонение } \\
\text { от стандар- } \\
\text { та, }\end{array}$ & $+3,8$ & $+0,6$ & $+1,5$ & $+1,9$ & $-1,6$ & $-0,2$ & $-0,6$ & $-0,8$ \\
\hline
\end{tabular}

* - на почвенном фоне, свободном от азотфиксирующих бактерий

Для сорта сои Барс разработан индивидуальный молекулярно-генетический паспорт на основе анализа ДНК методом ПЦР с использованием 11 микросателлитных локусов SSR. Методика проведения анализа и характеристика маркерных локусов приведена в ранее опубликованных работах P.B. Cregan с коллегами [11] и С.А. Рамазановой $[6 ; 7]$. Результаты ПЦР-анализа сорта сои Барс в виде индивидуального молекулярно-генетического паспорта приведены в таблице 3.

В целом, исследования показывают, что среднеранний сорт сои Барс отличается повышенной для своей группы спелости урожайностью, засухоустойчивостью, а также повышенной устойчивостью к пепельной 
гнили и фузариозному увяданию, что определяет его потенциальную привлекательность для сельхозтоваропроизводителей. В связи с этим в 2017 г. сорт Барс был передан на Государственное сортоиспытание по Северо-Кавказ-скому, Нижневолжскому и Дальневосточному регионам Российской Федерации (рис. 3).

\section{Таблица 3}

\section{Молекулярный паспорт сорта сои Барс}

ЦЭБ ВНИИМК, 2017-2018 гг.

\begin{tabular}{|l|c|c|}
\hline \multicolumn{1}{|c|}{ Локус } & Аллели & Молекулярный вес (п.н.) \\
\hline Satt1 & 2 & $141-150$ \\
\hline Satt 2 & 1 & $140-152$ \\
\hline Satt5 & 1 & $157-177$ \\
\hline Soypr 1 & 2 & $163-188$ \\
\hline Sat 1 & 1 & $188-235$ \\
\hline Sat36 & 1 & $115-185$ \\
\hline Sat43 & 1 & $157-203$ \\
\hline Soyhsp176 & 1 & $118-135$ \\
\hline Satt141 & 2 & $134-190$ \\
\hline Satt681 & 3 & $176-224$ \\
\hline Satt161 & 4 & $190-245$ \\
\hline
\end{tabular}

Помимо трёх регионов Российской Федерации, где проводится государственное сортоиспытание среднераннего сорта Барс, для его интродукции и выращивания также пригоден ряд областей с развитыми системами орошения в центральной и южной частях Республики Казахстан на 44$50^{\circ}$ с.ш., а также всей территории Республик Узбекистан и Кыргызстан.

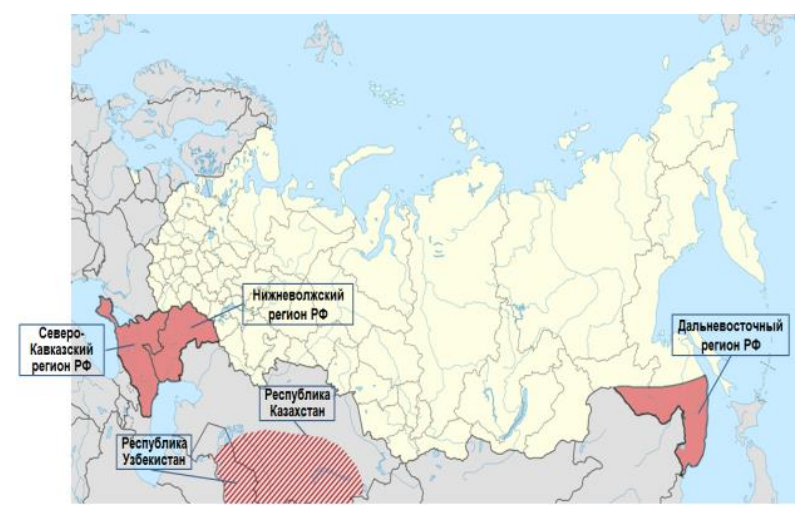

Рисунок 3 - Зоны государственного сортоиспытания сорта Барс в Российской Федерации и пригодные для возделывания этого сорта зоны в Республиках Казахстан и Узбекистан

\section{Список литературы}

1. Зеленщов С.В., Мошненко Е.В. Пути адаптации сельского хозяйства России к глобальным изменениям климата на примере экологической селекции сои // Научный диалог. - 2012. - № 7: Естествознание и экология. - С. 40-59.

2. Зеленциов С.В., Мошненко Е.В. Перспективы селекции высокобелковых сортов сои: Моделирование механизмов увеличения белка в семенах (Сообщение I) // Масличные культуры. Науч.-тех. бюл. ВНИИМК. - 2016. - Вып. 2 (166). - С. 34 41.

3. Зелениов С.В., Саенко Г.М., Лучинский А.С., Саломатина В.П. Способ отбора исходного материала для селекции сои с комплексной устойчивостью к возбудителям пепельной гнили и фузариозного увядания: патент РФ на изобретение № 2433168 , Заявка № 2010116317; заявл. 23.04.10 г. зарегистр. 10.11.11 г.

4. Зеленцов С.В., Кочегура А.В. К вопросу о внутривидовой классификации сои // Современные проблемы селекции и технологии возделывания сои: сб. статей 2-й межд. конф. по сое, Россия, Краснодар, 910 сентября 2008 г. - С. 178-193.

5. Зелениов С.В., Лучинский А.С. Усовершенствованная классификация типов роста сои // Масличные культуры. Науч.тех. бюл. ВНИИМК. - 2011. - Вып. 2 (148-149). - С. 88-94.

6. Рамазанова С.A. Идентификация генотипов сои разного происхождения с использованием полиморфизма девяти микросателлитных локусов ДНК // Современные проблемы селекции и технологии возделывания сои: сб. статей 2-й международной конференции по сое, Россия, Краснодар, 9-10 сентября 2008 г. - С. 129-136.

7. Рамазанова С.А. Идентификация сортов сои (Glycine max L.) с использованием микросателлитных локусов ДНК // Масличные культуры. Науч.-тех. бюл. ВНИИМК. - 2016. - Вып. 2 (166). - С. 63-67.

8. Саенко Г.М. Особенности патогенеза гриба Macrophomina phaseolina (Tassi.) Goid. на сое и селекционные меры снижения его вредоносности: дис. на соиск. ... канд. биол. наук. - КубГАУ, Краснодар, 2011. - С. 141-157.

9. Саенко Г.М., Зеленщов С.В., Пивень В.T. Использование особенностей 
гриба Macrophomina phaseolina (Tassi.) Goid. в селекции сои на толерантность к пепельной гнили (Сообщение II) // Масличные культуры. Науч.-тех. бюл. ВНИИМК. 2013. - Вып. 2 (155-156). - С. 32-42.

10. Саенко Г.М., Лучинский А.С., Зеленцов C.B. Сортовой полиморфизм сои по динамике осмотического давления клеточного сока растений в онтогенезе в связи с чувствительностью к возбудителю пепельной гнили - Macrophomina phaseolina (Tassi.) Goid. // Современные проблемы селекции и технологии возделывания сои: сб. статей 2-й межд. конф. по сое, Россия, Краснодар, 9-10 сентября 2008 г. - Краснодар, 2008. - С. 104-112.

11. Cregan P.B., Jarvik T., Bush A.L., Shoemaker R.C., Lark K.G., Kahler A.L., Van Toai T.T., Lohnes D.G., Chung J., Specht J.E. An integrated genetic linkage map of soybean // Crop Science. - 1999. Vol. 39. - P. 1464-1490.

\section{References}

1. Zelentsov S.V., Moshnenko E.V. Puti adaptatsii sel'skogo khozyaistva Rossii k global'nym izmeneniyam klimata na primere ekologicheskoi selektsii soi // Nauchnyi dialog. - 2012. - № 7: Estestvoznanie i ekologiya. - S. 40-59.

2. Zelentsov S.V., Moshnenko E.V. Perspektivy selektsii vysokobelkovykh sortov soi: Modelirovanie mekhanizmov uvelicheniya belka V semenakh (Soobshchenie I) // Maslichnye kul'tury. Nauch.-tekh. byul. VNIIMK. - 2016. - Vyp. 2 (166). - S. 34-41.

3. Zelentsov S.V., Saenko G.M., Luchinskii A.S., Salomatina V.P. Sposob otbora iskhodnogo materiala dlya selektsii soi s kompleksnoi ustoichivost'yu $\mathrm{k}$ vozbuditelyam pepel'noi gnili i fuzarioznogo uvyadaniya: patent RF na izobretenie № 2433168, Zayavka № 2010116317; zayavl. 23.04.10 g. zaregistr. 10.11.11 g.

4. Zelentsov S.V., Kochegura A.V. K voprosu o vnutrividovoi klassifikatsii soi // Sovremennye problemy selektsii i tekhnologii vozdelyvaniya soi: sb. statei 2-i mezhd. konf. po soe, Rossiya, Krasnodar, 9-10 sentyabrya 2008 g. - S. 178-193.

5. Zelentsov S.V., Luchinskii A.S. Usovershenstvovannaya klassifikatsiya tipov rosta soi // Maslichnye kul'tury. Nauch.-tekh. byul. VNIIMK. - 2011. - Vyp. 2 (148-149). S. 88-94.

6. Ramazanova S.A. Identifikatsiya genotipov soi raznogo proiskhozhdeniya $s$ ispol'zovaniem polimorfizma devyati mikrosatellitnykh lokusov DNK // Sovremennye problemy selektsii i tekhnologii vozdelyvaniya soi: $s b$. statei $2-i$ mezhdunarodnoi konferentsii po soe, Rossiya, Krasnodar, 9-10 sentyabrya 2008 g. - S. 129-136.

7. Ramazanova S.A. Identifikatsiya sortov soi (Glycine max L.) $\mathrm{s}$ ispol'zovaniem mikrosatellitnykh lokusov DNK // Maslichnye kul'tury. Nauch.-tekh. byul. VNIIMK. 2016. - Vyp. 2 (166). - S. 63-67.

8. Saenko G.M. Osobennosti patogeneza griba Macrophomina phaseolina (Tassi.) Goid. na soe i selektsionnye mery snizheniya ego vredonosnosti: dis. na soisk. ... kand. biol. nauk. - KubGAU, Krasnodar, 2011. - S. 141157.

9. Saenko G.M., Zelentsov S.V., Piven' V.T. Ispol'zovanie osobennostei griba Macrophomina phaseolina (Tassi.) Goid. v selektsii soi na tolerantnost' $\mathrm{k}$ pepel'noi gnili (Soobshchenie II) // Maslichnye kul'tury. Nauch.tekh. byul. VNIIMK. - 2013. - Vyp. 2 (155156). - S. 32-42.

10. Saenko G.M., Luchinskii A.S., Zelentsov S.V. Sortovoi polimorfizm soi po dinamike osmoticheskogo davleniya kletochnogo soka rastenii $\mathrm{v}$ ontogeneze $\mathrm{v}$ svyazi $\mathrm{s}$ chuvstvitel'nost'yu k vozbuditelyu pepel'noi gnili Macrophomina phaseolina (Tassi.) Goid. // Sovremennye problemy selektsii i tekhnologii vozdelyvaniya soi: sb. statei 2 -i mezhd. konf. po soe, Rossiya, Krasnodar, 9-10 sentyabrya 2008 g. - Krasnodar, 2008. - S. 104-112.

11. Cregan P.B., Jarvik T., Bush A.L., Shoemaker R.C., Lark K.G., Kahler A.L., Van Toai T.T., Lohnes D.G., Chung J., Specht J.E. An integrated genetic linkage map of soybean // Crop Science. - 1999. - Vol. 39. - P. 1464 1490.

Получено: 09.07.2018 Принято: 01.04.2019

Received: 09.07.2018 Accepted: 01.04.2019 